\title{
EPIDEMIOLOGICAL CHARACTERISTICS AND CAUSES OF PROXIMAL FEMORAL FRACTURES AMONG THE ELDERLY
}

\author{
José Soares Hungria Neto', Caio Roncon Dias ${ }^{2}$, José Daniel Bula de Almeida ${ }^{2}$
}

\section{ABSTRACT}

Objective: The social and economic cost of proximal femoral fractures is high, due the morbidity and mortality relating to the fracture itself, among other factors. Despite the importance of this issue, studies on this topic are still scarce in Brazil. This was a retrospective, observational and cross-sectional (ecological) study with the aims of outlining an epidemiological profile for proximal femoral fractures among the elderly and analyzing the causes of these fractures and the physical characteristics of patients admitted to a single university hospital in São Paulo. Methods: This was a study on medical records over a oneyear period, with group comparisons using the chi-square test; $\mathrm{p}<0.05$ was considered significant. Results: Ninety-four individuals were evaluated: predominantly female $(2: 1) ; 81-85$ years of age; body mass index within normal limits; white and
Asian patients $(\mathrm{p}<0.05)$. The vast majority of the fractures occurred through low-energy trauma and inside the patients' homes $(\mathrm{p}<0.05)$. After excluding the trauma resulting from high-energy events, over 39\% occurred as the patients were moving from sitting to standing up or were using stairs, and approximately $40 \%$ occurred while they were standing still or walking. A greater number of cases corresponded to the cold seasons of the year $(\mathrm{p}<0.05)$; Conclusion: Most injuries occurred inside the patients' own homes and had low-energy causes. Thus, some accidents might be avoided through simple low-cost measures that guide the elderly regarding situations of risk, which would bring major quality-of-life benefits and significant decreases in morbidity, mortality and the socioeconomic costs of this increasingly frequent problem.

Keywords - Femoral Fractures; Aged; Epidemiology

\section{INTRODUCTION}

The number of elderly individuals aged 60 years or over (Brazilian legislation), has been increasing year by year, both in the world population and in Brazil. According to the Brazilian Institute of Geography and Statistics (IBGE), in 1950 there were about 204 million elderly individuals in the world; while in 1998, this group reached 579 million. The projections indicate that, in 2050, the elderly population will amount to 1.9 billion people. Nowadays, one in every 10 people is aged 60 years or over, and it is estimated that the worldwide ratio will be one to five in 2050 . In Brazil, elderly people corresponded to $4.2 \%$ of the population in 1950 , while in the year 2000, they represented $8.6 \%$ and, in 2020, are expected to correspond to $14 \%$, or about 31 million people.

This increase is mainly due to the better living conditions and to the constant advance of medicine, increasing the population's life expectancy. However, this aging accompanies the problems of old age, such as proximal femoral fractures, a common and important cause of morbidity and mortality in this age bracket.

Proximal femoral fractures in elderly individuals generally result from low-energy trauma, such as falls, and are related to various factors, such as: advanced age, osteoporosis, diminishing muscle strength, hip geometry, ingestion of calcium and vitamin D and ge-

1 - Adjunct Professor of the Santa Casa de São Paulo; Vice Dean of the Faculdade de Ciências Médicas da Santa Casa de São Paulo - São Paulo, SP, Brazil.

2 - Sixth-year Medical Student of the Faculdade de Ciências Médicas da Santa Casa de São Paulo - São Paulo, SP, Brazil.

Study conducted at the Department of Orthopedics and Traumatology of the Faculdade de Ciências Médicas da Santa Casa de São Paulo, Pavilhão Fernandinho Simonsen da Irmandade da Santa Casa de Misericórdia de São Paulo.

Mailing address: Faculdade de Ciências Médicas da Santa Casa de São Paulo, Departamento de Ortopedia e Traumatologia, Rua Dr. Cesário Motta Jr., 112, Santa Cecília 01221-020 - São Paulo, SP, Brazil. Email: jose.hungria@fcmscsp.edu.br

Study received for publication: 10/12/2010, accepted for publication: 12/23/2011.

The authors declare that there was no conflict of interest in conducting this work

This article is available online in Portuguese and English at the websites: www.rbo.org.br and www.scielo.br/rbort 
netic predisposition ${ }^{(1-11)}$. Porter et $\mathrm{al}^{(12)}$ demonstrated that the main factor that leads to an increase in the incidence of these fractures in the over- 60 age bracket is the presence of osteoporosis, as well as the higher incidence of falls. Approximately one third of white women over 65 years of age have osteoporosis ${ }^{(13)}$, and $30 \%$ of elderly women fall at least once a year ${ }^{(1)}$. It is estimated that 6,000,000 individuals in the world will suffer a proximal femoral fracture in the year $2050^{(12)}$.

Sakaki et al ${ }^{(14)}$ showed that $5.5 \%$ of patients with proximal femoral fracture die during their hospital stay; $4.6 \%$, at the end of one month of follow-up; $11.9 \%$, after three months; $10.8 \%$, after six months; $19.2 \%$, after a year; and $24.9 \%$, after two years. Cunha and Veado ${ }^{(15)}$ showed mortality of $25 \%$ in one year. Four factors are closely related to mortality: advanced age, number of comorbidities, male sex and presence of cognitive deficiencies ${ }^{(14)}$.

The social and economic cost of femoral fractures is high, and results, among other factors, from the morbimortality of the fracture itself and from the associated diseases, from a variable period of hospitalization, often in an intensive care unit, clinical and surgical care, besides rehabilitation programs over prolonged periods of time ${ }^{(16)}$. And, in the period of one year, just $40.5 \%$ of the patients are totally independent in their activities of daily living ${ }^{(15)}$.

In spite of the importance of proximal femoral fractures, epidemiological studies involving this topic are still scarce in Brazil. The aim of this study is to outline an epidemiological profile of this type of fracture in elderly individuals, and to analyze its causes, studying the physical characteristics of the patients with this type of injury admitted to the Department of Orthopedics and Traumatology "Pavilhão Fernandinho Simonsen", Irmandade Santa Casa de Misericórdia de São Paulo.

\section{PATIENTS AND METHODS}

This was a retrospective, observational and cross- sectional (ecological) study. The inclusion criterion gathered all the patients with proximal femoral fractures over 59 years of age, who were hospitalized in the Department of Orthopedics and Traumatology "Pavilhão Fernandinho Simonsen", Irmandade Santa Casa de Misericórdia de São Paulo, in the period between April 1, 2004 and March 31, 2005.

Patients with this type of fracture, yet under 60 years of age, were excluded from the study.

We gathered information on this group of patients through a study of their medical records, obtaining anthropometric data, age, sex and ethnicity, associated diseases and use of medications (Chart 1).

The year was divided into four seasons, by quarter: fall (April, May and June 2004); winter (July, August and September 2004); spring (October, November and December 2004); and summer (January, February and March 2005). The number of fractures by season was added up in search of a possible seasonal variation.

The analyses by age bracket were divided into five-year intervals for better processing of the gathered data and in order to facilitate the comparison with previous studies.

The body mass index (BMI) was calculated in all the patients to analyze the possible existence of a more susceptible group, as well as ethnicity, the place where the fracture occurred, its cause, previous use of medications and other associated comorbidities.

To analyze cause, the patients were divided into those with high and low-energy trauma. Accidents involving an external factor of impact, such as run over victims and falls from considerable heights (such as the roof), were considered high-energy traumas, while falls from own height or from stairs and patients who did not remember the occasion of the fracture (sought medical care due to pain with the verification of a fracture) were considered low- energy traumas.

Chart 1- Data collection.

\begin{tabular}{|c|c|}
\hline Date of collection & \multirow[t]{4}{*}{ Cause } \\
\hline Hospital bed & \\
\hline Name & \\
\hline Age & \\
\hline Sex & \multirow[t]{5}{*}{ Diseases } \\
\hline Color & \\
\hline Weight & \\
\hline Height & \\
\hline Leg & \\
\hline Date of accident & \multirow[t]{4}{*}{ Medications } \\
\hline Time of accident & \\
\hline Date of hospitalization & \\
\hline Time of hospitalization & \\
\hline
\end{tabular}


For statistical analysis we used the chi-square test, which compared the actual interval obtained with the expected interval, i.e., the expected value at which the cases are distributed mathematically equal to one another.

\section{RESULTS}

We reviewed the medical records of 94 patients, of whom 31 were men (33\%) and 63 women (67\%), demonstrating female predominance of 2:1 (Table 1).

The mean age found was 78.2 years, with a standard deviation (SD) of 9.18. The calculated median resulted in 79 years (ranging from 60 to 101 years). We observed a statistical difference in terms of the patient's age ( $p<$ 0.05 ), showing that the number of cases per age bracket did not exhibit homogeneous distribution. The highest number of proximal femoral fractures occurred in women between 81-85 years of age. As regards the men, fractures also predominated in the age bracket between 81-85 years (Figure 1), taking into account that in the bracket between $60-64$ years, $50 \%$ of the cases were caused by high-energy trauma.

Analyzing each one of the sexes individually, the age of the male patients averaged 75.5 years (SD of 10.1 and median of 77 years) while that of the female patients averaged 79.6 years (SD of 8.4 and median of 80 years).

The patients' mean body mass index $(\mathrm{BMI}=$ weight $/$ height $^{2}$ ) was $22.6 \mathrm{~kg} / \mathrm{m}^{2}$ (with 21.8 in the men and 22.9 in the women), keeping in mind that the range considered normal is 19 to $25 \mathrm{~kg} / \mathrm{m}^{2}$.

As regards ethnicity, it was observed that approximately $93.6 \%$ of the patients were white or Asian, against only $6.4 \%$ of blacks or individuals of mixed race $(p<0.05)$.

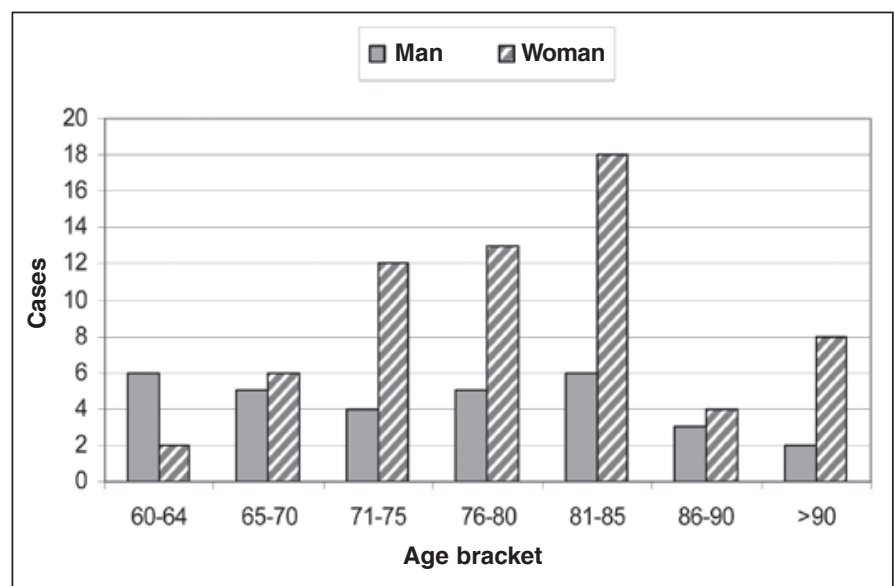

Figure 1 - Distribution of the number of cases according to sex and age bracket(years).
As regards comorbidities, $84 \%$ of the medical records contained personal history in the anamnesis; of these, $72 \%$ presented some comorbidity $(p<0.05)$, with $31.7 \%$ hypertensive and $16.5 \%$ diabetic patients, $8.9 \%$ with some neurological disease (Parkinson's or Alzheimer's, for example) and $13.9 \%$ presented a previous diagnosis of osteoporosis.

In 79 medical records there is a description of the place where the fracture occurred. Of these, $73.4 \%$ suffered the trauma inside their own home $(p<0.05)$. There was a statistically significant difference ( $p=0.026)$ between the patients' location at the time of the trauma when separated by sex $(42 \%$ of the men were outside the home, against $19 \%$ of the women) (Figure 2).

Of the patients that suffered fractures in external environments, $73 \%$ of the cases in men occurred due to high-energy trauma, such as being run over by a vehicle or a fall from the roof, against just $20 \%$ of high-energy trauma among the women who were outside their own homes.

A difference was observed in relation to the number of cases according to the month of the year $(p<0.05)$, with fractures predominating in June, July and August (Figure 3).

As regards the seasonality of the proximal femoral fracture, grouping the months according to the respective seasons of the year, note the predominance of cases of proximal femoral fracture in the period corresponding to fall and to winter, recording 28 and 29 cases, respectively; during spring, we observed 17, and in summer there were 20 (Figure 4). These values did not demonstrate statistical significance $(p=0.215)$; yet when we associate the two coldest seasons (fall and winter) and compare them with the combination of the warmest seasons (spring and summer), we obtain statistical significance $(p<0.05)$.

Evaluating just the cause of the fracture, of the 79 medical records that included this information, $87 \%$ had their trauma resulting from low energy $(\mathrm{p}<0.05)$. Of these, $40.6 \%$ were due to falls when walking or even with the patient standing still, $27.5 \%$ of the fractures occurred while getting up (from bed, or from a chair or sofa), $11.6 \%$ were due to falls on staircases and $4.3 \%$ were caused by stumbling while walking (due to some kind of obstacle). It was also observed that of this group of patients, $26 \%$ of them experienced a sensation of dizziness or vertigo at the time of the accident (Figure 5). 
Table 1 - Results.

\begin{tabular}{|c|c|c|c|c|c|c|c|c|}
\hline \multirow[t]{2}{*}{ Variable } & \multirow[t]{2}{*}{ Category } & \multicolumn{2}{|c|}{ Man } & \multicolumn{2}{|c|}{ Woman } & \multicolumn{2}{|c|}{ Total } & \multirow[t]{2}{*}{$\mathbf{p}$} \\
\hline & & no. & $\%$ & no. & $\%$ & no. & $\%$ & \\
\hline \multirow[t]{3}{*}{ Age } & Mean & 75.5 & & 79.6 & & 78.2 & & \\
\hline & Standard deviation & 10.1 & & 8.4 & & 9.18 & & \\
\hline & Median & 77 & & 80 & & 79 & & \\
\hline \multirow{8}{*}{ Age bracket } & $60-64$ & 6 & 6.3 & 2 & 2.1 & 8 & 8.5 & \\
\hline & $65-70$ & 5 & 5.3 & 6 & 6.3 & 11 & 11.7 & \\
\hline & $71-75$ & 4 & 4.2 & 12 & 12.7 & 16 & 17 & \\
\hline & $76-80$ & 5 & 5.3 & 13 & 13.8 & 18 & 19.1 & \\
\hline & $81-85$ & 6 & 6.3 & 18 & 19.1 & 24 & 25.5 & \\
\hline & $86-90$ & 3 & 3.2 & 4 & 4.2 & 7 & 7.4 & \\
\hline & $>90$ & 2 & 2.1 & 8 & 8.5 & 10 & 10.6 & \\
\hline & Total & 31 & 33 & 63 & 67 & 94 & 100 & 0.009 \\
\hline \multirow[t]{12}{*}{ Month } & April & 2 & 2.1 & 5 & 5.3 & 7 & 7.4 & \\
\hline & May & 4 & 4.2 & 5 & 5.3 & 9 & 9.5 & \\
\hline & June & 5 & 5.3 & 7 & 7.4 & 12 & 12.7 & \\
\hline & July & 5 & 5.3 & 9 & 9,5 & 14 & 14,8 & \\
\hline & August & 3 & 3.2 & 9 & 9.5 & 12 & 12.7 & \\
\hline & September & 3 & 3.2 & 0 & 0 & 3 & 3.2 & \\
\hline & October & 1 & 1 & 4 & 4.2 & 5 & 5.3 & \\
\hline & November & 0 & 0 & 4 & 4.2 & 4 & 4.2 & \\
\hline & December & 2 & 2.1 & 6 & 6.3 & 8 & 8.5 & \\
\hline & January & 1 & 1 & 1 & 1 & 2 & 2.1 & \\
\hline & February & 3 & 3.2 & 8 & 8.5 & 11 & 11.7 & \\
\hline & March & 2 & 2.1 & 5 & 5.3 & 7 & 7.4 & 0.031 \\
\hline \multirow[t]{4}{*}{ Season } & Fall & 11 & 11.7 & 17 & 18 & 28 & 29.8 & \\
\hline & Winter & 11 & 11.7 & 18 & 19.1 & 29 & 30.8 & \\
\hline & Spring & 3 & 3.2 & 14 & 14.9 & 17 & 18.1 & \\
\hline & Summer & 6 & 6.3 & 14 & 14.9 & 20 & 21.3 & 0.215 \\
\hline \multirow[t]{2}{*}{ Season } & Fall + winter & 22 & 23.4 & 35 & 37.2 & 57 & 60.6 & \\
\hline & Spring + summer & 9 & 9.8 & 28 & 29.8 & 37 & 39.4 & 0.039 \\
\hline \multirow[t]{2}{*}{ Ethnicity } & Whites & 29 & 30.8 & 59 & 62.8 & 88 & 93.6 & \\
\hline & Blacks & 2 & 2.1 & 4 & 4.3 & 6 & 6.4 & $<0.05$ \\
\hline Mean BMI & & 21.8 & & 22.9 & & 22.6 & & \\
\hline \multirow[t]{3}{*}{ Place $^{*}$} & At home & 15 & 19 & 43 & 54.4 & 58 & 73.4 & \\
\hline & On the street & 11 & 13.9 & 10 & 12.6 & 21 & 26.6 & \\
\hline & Total & 26 & 32.9 & 53 & 67.1 & 79 & 100 & $<0.05$ \\
\hline \multirow{3}{*}{$\begin{array}{c}\text { Place individualized } \\
\text { by sex }\end{array}$} & At home & 15 & 57.7 & 43 & 81.1 & & & \\
\hline & On the street & 11 & 42.3 & 10 & 18.9 & & & 0.026 \\
\hline & High energy & 8 & 10.1 & 2 & 2.5 & 10 & 12.6 & \\
\hline \multirow[t]{2}{*}{ Trauma* } & Low energy & 18 & 22.7 & 51 & 64.5 & 69 & 87.3 & \\
\hline & Total & 26 & 32.9 & 53 & 67 & 79 & 100 & $<0.05$ \\
\hline \multirow{2}{*}{$\begin{array}{c}\text { Trauma individualized } \\
\text { by sex }\end{array}$} & High energy & 8 & 30.7 & 2 & 3.7 & & & \\
\hline & Low energy & 18 & 69.2 & 51 & 96.2 & & & $<0.05$ \\
\hline Low-energy & With dizziness or vertigo & & & & & 18 & 26 & \\
\hline trauma & Without & & & & & 51 & 73.9 & \\
\hline Trauma + place* & High-energy at home & 0 & 0 & 0 & 0 & 0 & 0 & \\
\hline
\end{tabular}




\begin{tabular}{|c|c|c|c|c|c|c|c|c|}
\hline \multirow[t]{2}{*}{ Variable } & \multirow{2}{*}{$\begin{array}{c}\text { Category } \\
\text { High-energy on the street }\end{array}$} & \multicolumn{2}{|c|}{ Man } & \multicolumn{2}{|c|}{ Woman } & \multicolumn{2}{|c|}{ Total } & \multirow[t]{2}{*}{$\mathbf{p}$} \\
\hline & & 8 & 10.1 & 2 & 2.5 & 10 & 12.6 & \\
\hline & Low-energy at home & 15 & 19 & 43 & 54.4 & 58 & 73.4 & \\
\hline & Low-energy on the street & 3 & 3.8 & 8 & 10.1 & 11 & 13.9 & \\
\hline & Total & 26 & 32.9 & 53 & 67.1 & 79 & 100 & \\
\hline Trauma + place & High-energy at home & 0 & 0 & 0 & 0 & & & \\
\hline individualized & High-energy on the street & 8 & 30.8 & 2 & 3.7 & & & \\
\hline \multirow[t]{2}{*}{ by sex ${ }^{\star}$} & Low-energy at home & 15 & 57.7 & 43 & 81.1 & & & \\
\hline & Low-energy on the street & 3 & 11.5 & 8 & 15.1 & & & \\
\hline Low energy + & Low-energy at home & 15 & 83.3 & 43 & 84.3 & & & \\
\hline place individualized & Low-energy on the street & 3 & 16.7 & 8 & 15.7 & & & \\
\hline \multirow[t]{2}{*}{ by sex ${ }^{*}$} & Total & 18 & 100 & 51 & 100 & & & \\
\hline & & & & & & & & \\
\hline Low-energy trauma & Fall walking or standing still & & & & & 28 & 40.6 & \\
\hline \multirow[t]{6}{*}{+ cause $^{*}$} & Fall in rising & & & & & 19 & 27.5 & \\
\hline & Fall from stairs & & & & & 8 & 11.6 & \\
\hline & Slipping & & & & & 8 & 11.6 & \\
\hline & Stumbling & & & & & 3 & 4.3 & \\
\hline & Others & & & & & 3 & 4.3 & \\
\hline & Total & & & & & 69 & 100 & \\
\hline & & & & & & & & \\
\hline Associated & Without & & & & & 22 & 27.8 & \\
\hline morbidities* & With & & & & & 57 & 72.1 & $<0.05$ \\
\hline Associated & Hypertension & 4 & 5.1 & 21 & 26.6 & 25 & 31.7 & \\
\hline \multirow[t]{4}{*}{ morbidities* } & Diabetes & 1 & 1.3 & 12 & 15.2 & 13 & 16.5 & \\
\hline & Osteoporosis** & 1 & 1.3 & 10 & 12.7 & 11 & 13.9 & \\
\hline & Alzheimer's & 3 & 3.8 & 1 & 1.3 & 4 & 5.1 & \\
\hline & Parkinson's & 1 & 1.3 & 2 & 2.5 & 3 & 3.8 & \\
\hline
\end{tabular}

* 79 of the $94(84 \%)$ medical records contained the situation in which the trauma occurred

** Patients diagnosed with osteoporosis prior to the trauma
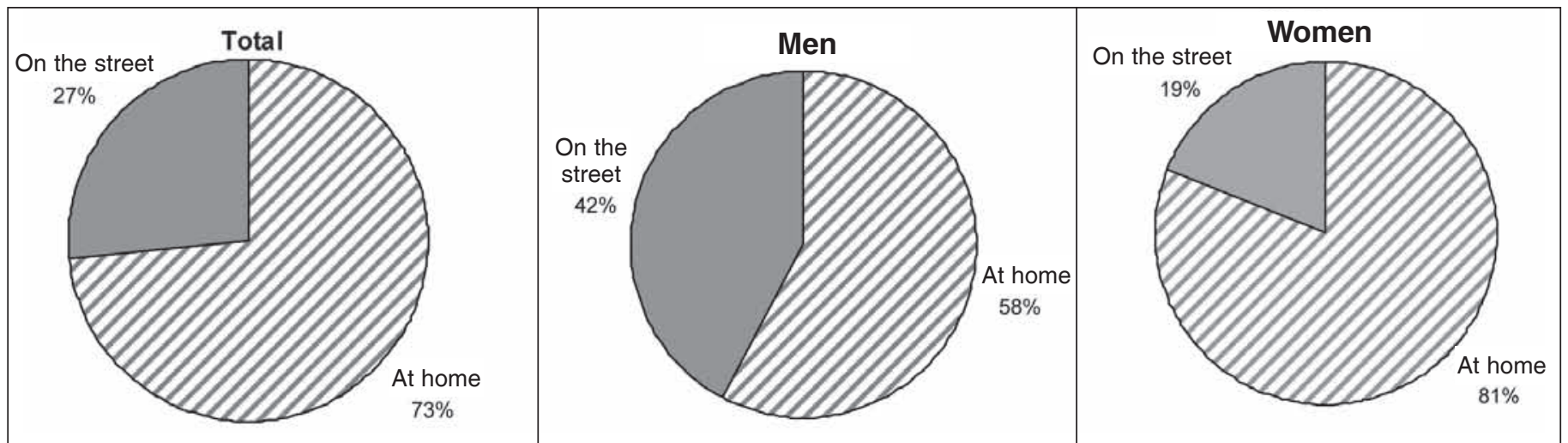

Figure 2 - Location of the patients at the time of trauma: total and divided by sex.

\section{DISCUSSION}

In this study we verified a mean body mass index (BMI) of 22.6 (without significant difference between men and women), i.e., the fractures occurred in people with BMI within the normal range (19-25) and not in overweight or obese people. This fact was also observed by other authors ${ }^{(17-19)}$. There are different hypotheses for this phenomenon: elderly individuals with a higher BMI generally present a larger quantity of muscle and fat tissue, with an increase of stress on the bone, leading to less mineral loss ${ }^{(18)}$; moreover, the excess fat and greater musculature, present due to 


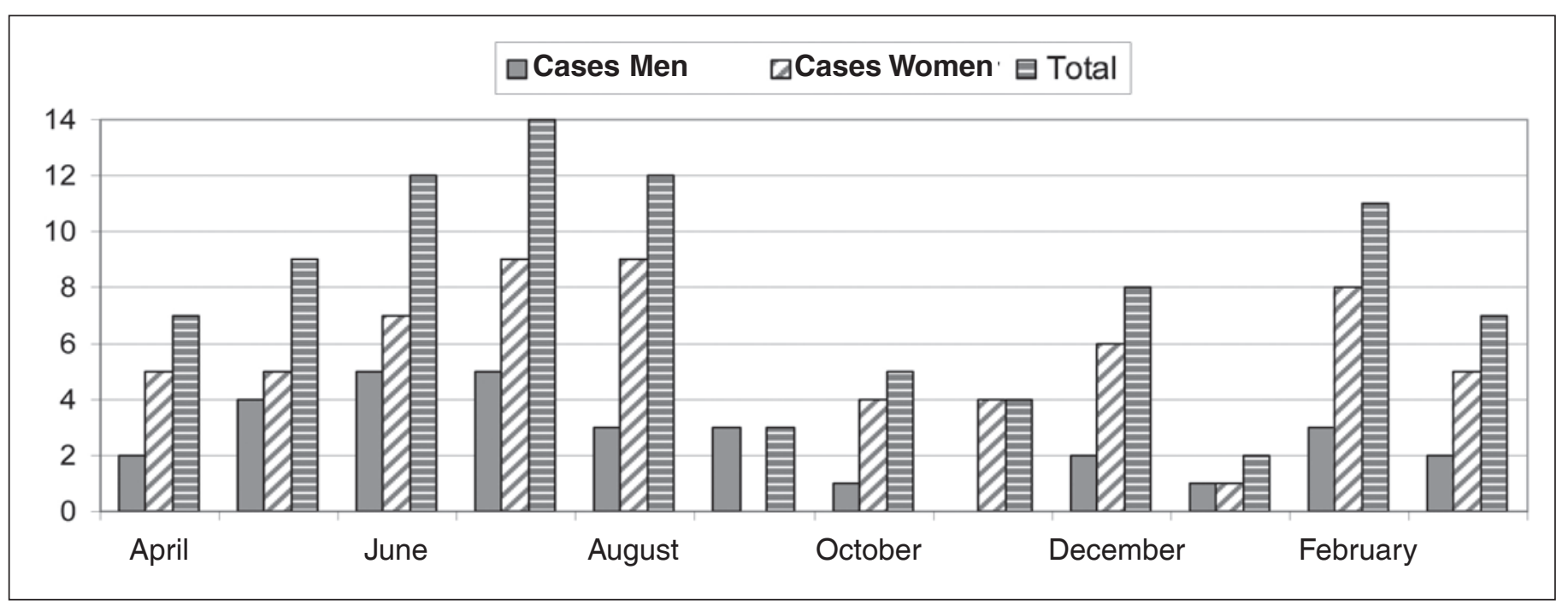

Figure 3 - Distribution of the number of cases according to sex and month.

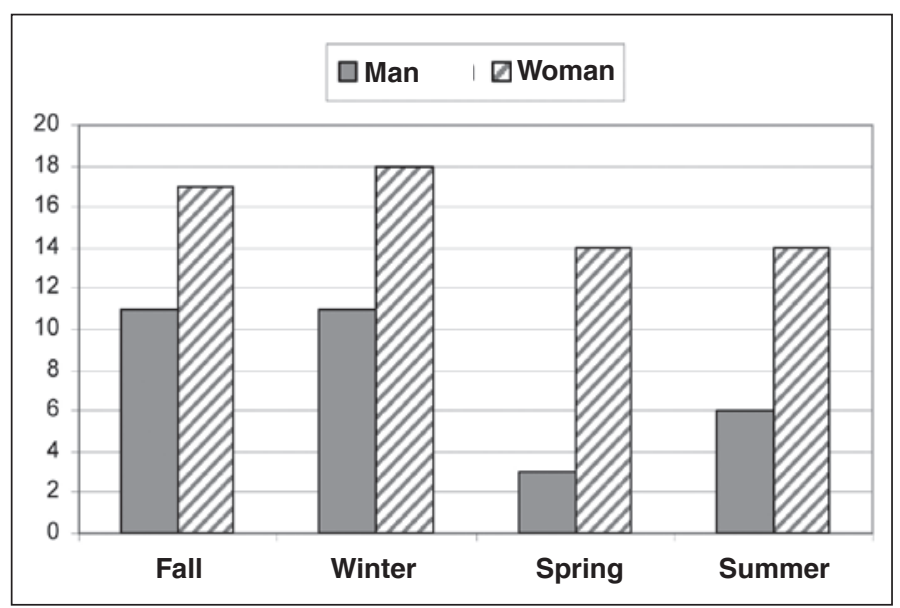

Figure 4 - Distribution of the number of cases according to sex and seasons.

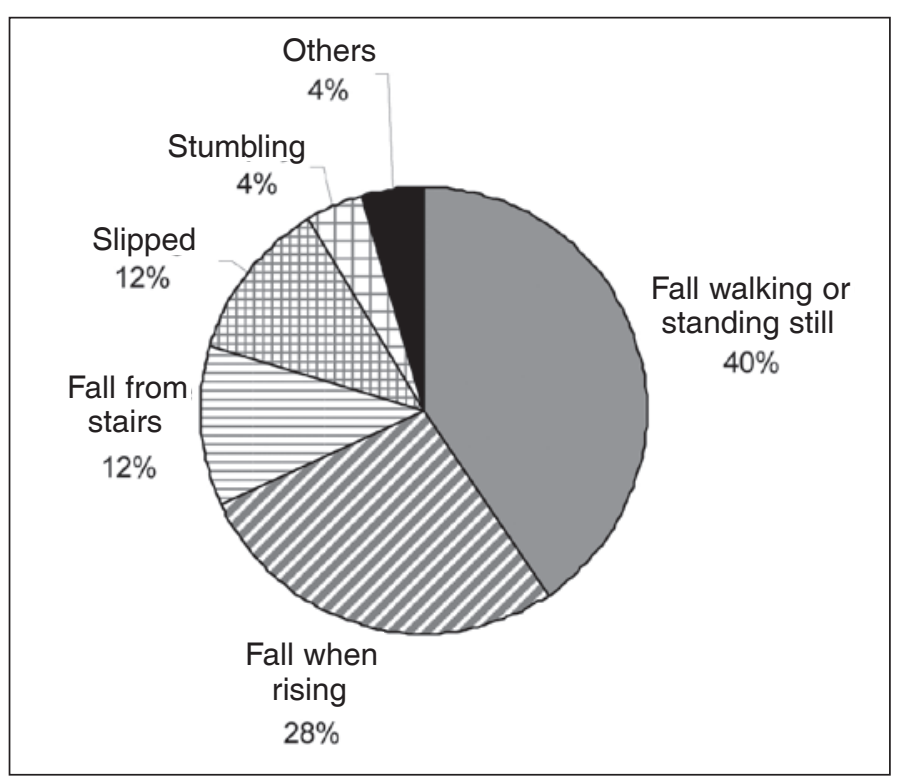

Figure 5 - Cause of the low-energy fractures. excess load, can act as a cushion for the hip, absorbing trauma in the region.

In this study we observed predominance of proximal femoral fractures in the female population $(2: 1)$. Although similar studies always show a greater incidence among female subjects, the ratio differs quantitatively among them: a study also conducted in São Paulo showed a ratio of 3.3:1 ${ }^{(17)}$; in Uberaba, 1.3:1 $1^{(2)}$; another, in La Plata, Argentina, of $3.8: 1^{(5)}$; while in Oxford, England, the authors observed $3: 1^{(20)}$; and, in Rome, Italy, $4.5: 1^{(21)}$. The difference encountered between the sexes is partly explained by the reduced bone density in postmenopausal females ${ }^{(3)}$.

The mean age found was 78.2, similar to that found in the study also conducted in the city of São Paulo, where the age averaged 78.5 $5^{(17)}$ and in Belo Horizonte, averaging 79 years ${ }^{(15)}$ and scarcely different from that conducted in Uberaba with mean age of 68 years ${ }^{(2)}$. The female median of 80 years was also similar ${ }^{(2,17)}$. The mean age in the males was lower ( 77 years), also similar to the abovementioned studies ${ }^{(5,17)}$.

Unlike other studies, in relation to the male sex, the authors did not find a considerable variation in the percentage of cases in the different age brackets, in fact there was a decrease in the incidence of fractures above the age of 85 years. But it is worth noting that the percentage of the male population decreases faster than the female population with age, and that, of the cases of younger male patients studied in this article (11 patients aged between 60 and 69 years, 35\%), $56 \%$ had suffered high-energy trauma (such as falling from a roof). 
A low rate of fractures was observed in black patients (6.4\% against $93.6 \%$ in the white population), similar to the value found in literature of $6.2 \%{ }^{(2)}$. An explanation for this occurrence is that blacks present greater bone mass accumulation, which must be related to the greater renal calcium reabsorption and resistance to the action of parathormone (PTH) on bone $^{(22)}$; in addition, according to some studies, black individuals exhibit lower levels of osteocalcin, of the bone fraction of alkaline phosphatase and of urinary hydroxyproline ${ }^{(23,24)}$.

A significant difference was observed between the sexes as regards the place where the patient suffered the facture: while $81 \%$ of the women were at home, only $58 \%$ of the men were also inside the home. But, considering only the cases of low-energy trauma, it is verified that $84 \%$ of the total patients experienced a fracture inside the home, with $83 \%$ of the cases involving male and $84 \%$ female patients, a very similar result between the sexes. This fact demonstrates that, if we remove high-energy trauma from the equation, most of the patients suffered the fracture inside their own homes $(\mathrm{p}<0.05)$.

Of the patients whose fractures occurred in external environments, $73 \%$ of the cases in men occurred due to high-energy trauma (patients run over by vehicles, falls from a roof, etc.) against just $19 \%$ of the women.

All told, $87.3 \%$ of the fractures resulted from low- energy trauma, a result higher than the $73.5 \%$ found in literature ${ }^{(2)}$. Analyzing just these fractures, it is verified that most of the patients fell while standing, either walking or standing still. This fall can often be associated with an episode of weakness or sensation of dizziness. It was also noticed that most of the patients fell while rising from a seated or lying position, connecting a lower percentage of fractures to minor accidents, such as falling from the stairs or stumbling.

As regards the presence of comorbidities, it is known that individuals within the age bracket of this study, in general, already have some kind of disease and pharmacological dependence. This study showed that the patients already presented some associated disease, with hypertension, diabetes mellitus and osteoporosis predominating; it is also important to keep in mind that the same patient can present more than one associated pathology, which is not uncommon.

The seasonal variation in the incidence of femoral fractures is implied by the greater quantity of cases occurring in the period corresponding to winter (more specifically end of fall and winter). Some studies did not find this seasonal variation ${ }^{(25-28)}$, but the result obtained was similar to that found in other studies $^{(29-32)}$.

Although the cause of this variation is still uncertain, some explanations include a decrease in neuromuscular coordination and vitamin $\mathrm{D}$ deficiency in winter periods ${ }^{(33)}$. This is due to the essential effect that vitamin D produces in calcium absorption, increasing it in the intestinal tract; moreover, there is an influence on bone deposition and resorption.

Although this study did not feature an evaluation of daily physical activity, including a control group, it is important to emphasize that literature $e^{(18,34,35,36)}$ shows a retrospective history of low daily physical activity in individuals with proximal femoral fracture in comparison to individuals from the group without the same fracture. Cooper et $\mathrm{al}^{(35)}$ verified that, in both sexes, an increase in activity, including walks, climbing stairs, working in the house and in the garden, protects against these fractures. This is due to the increase of strength resulting from muscular demands above the basal level, resulting in a greater load on the bones and, consequently, an increase of bone mineral density, besides the fact that the actual muscle mass acts as local protection against trauma.

\section{CONCLUSION}

In this study we observed a female predominance of 2:1 in patients with mean age of 78.2 years, with a greater risk especially for the age bracket of 81-85 years. The mean body mass index (BMI) observed was $22.6 \mathrm{~kg} / \mathrm{m}^{2}$.

We also verified the prevalence of fractures in white individuals and in patients with one or more associated comorbidities.

There was a predominance of fractures in colder periods of the year (fall and winter).

Most fractures occurred inside the patients' own homes and were due to low-energy trauma.

Of the patients whose fractures occurred due to low-energy trauma, note that more than $38 \%$ 
of the accidents could have been avoided, as they occurred when the patient was rising from a seated or lying position or was using the stairs. To this end, simple and economical epidemiological measures that counsel and instruct the elderly population to rise cautiously (from bed in the morning, or from a chair, or while getting out of the car), and to be more careful while descending stairs, can reduce the incidence of proximal femoral fractures by approximately $40 \%$, bringing substantial benefits in the quality of life of the elderly population, besides producing an enormous decrease of morbimortality and of the socioeconomic costs of this increasingly frequent problem.

\section{REFERENCES}

1. Carvalho MI. Osteoporose: visão do ortopedista. Rev Bras Ortop. 2006;41(4):91-7.

2. Rocha MA, Carvalho WS, Zanqueta C, Lemos SC. Estudo epidemiológico retrospectivo das fraturas do fêmur proximal tratados no Hospital Escola da Faculdade de Medicina do Triângulo Mineiro. Rev Bras Ortop. 2001;36(8):311-6.

3. Cummings SR, Kelsey JL, Nevitt MC, O'Dowd KJ. Epidemiology of osteoporosis and osteoporotic fractures. Epidemiol Rev. 1985;7:178-208.

4. Brumel JE, Ayarza E, Pavez A, Silva I. Incidencia de fractura de cuello de fêmur (FCF), area sur y sur oriente de Santiago. Cuad Med Soc. 1991;32(1):9-15.

5. Bagur A, Mautalen C, Rubin Z. Epidemiology of hip fractures in an urban population of central Argentina. Osteoporos Int. 1994;4(6):332-5.

6. Heyse SP, Sartori L, Crepaldi G. Epidemiology of osteoporosis: a study of fracture mortality in Italy. Calcif Tissue Int. 1990;46(5):289-93.

7. Cummings SR. Are patients with hip fractures more osteoporotic? Review of the evidence. Am J Med. 1985;78(3):487-94.

8. Dargent-Molina P, Favier F, Grandjean H, Baudoin C, Schott AM, Hausherr E, et al. Fall-related factors and risk of hip fracture: the EPIDOS prospective study. Lancet. 1996;348(9021):145-9.

9. Faulkner KG, Cummings SR, Black D, Palermo L, Glüer CC, Genant HK. Simple measurement of femoral geometry predicts hip fracture: the study of osteoporotic fractures. J Bone Miner Res. 1993;8(10):1211-7.

10. Chapuy MC, Arlot ME, Duboeuf F, Brun J, Crouzet B, Arnaud S, et al. Vitamin D3 and calcium to prevent hip fractures in the elderly women. N Engl J Med. 1992;327(23):1637-42.

11. Black DM. Screening and treatment in the elderly to reduce osteoporotic fracture risk. Br J Obstet Gynaecol. 1996;103(Suppl 13):2-7.

12. Porter RW, Miller CG, Grainger D, Palmer SB. Prediction of hip fracture in elderly women: a prospective study. BMJ. 1990;301(6753):638-41.

13. Guarniero R, Oliveira LG. Osteoporose: atualização no diagnostico e princípios básicos para o tratamento. Rev Bras Ortop. 2004;49(9):477-85.

14. Sakaki MH, Oliveira AR, Coelho FF, Garcez LEL, Suzuki I, Amatuzzi MM. Estudo da mortalidade na fratura do fêmur proximal em idosos. Acta Ortop Bras 2004;12(4):242-9.

15. Cunha U, Veado MA. Fratura da extremidade proximal do fêmur em idosos: independência funcional e mortalidade em um ano. Rev Bras Ortop. 2006;41(6):195-9.

16. Hannan EL, Magaziner J, Wang JJ, Eastwood EA, Silberzweig SB, Gilbert M, et al. Mortality and locomotion 6 months after hospitalization for hip fracture: risk factors and risk-adjusted hospital outcomes. JAMA. 2001;285(21):2736-42

17. Ana CR, Lazaretti-Castro M; Hauache O; Vieira JG, Takata E, Cafalli F. Osteoporotic fractures of proximal fêmur: clinical and epidemiological features in a population of the city of São Paulo. Sao Paulo Med J. 2001;119(2):48-53.

18. Farmer ME, Harris T, Madans JH, Wallace RB, Cornoni-Huntley J, White LR. Anthropometric indicators and hip fracture. The NHANES I epidemiologic followup study. J Am Geriatr Soc. 1989;37(1):9-16.

19. Bauer DC, Browner WS, Cauley JA, Orwoll ES, Scott JC, Black DM, Tao $\mathrm{JL}$, Cummings SR. Factors associated with appendicular bone mass in older women. The Study of Osteoporotic Fractures Research Group. Ann Intern Med. 1993;118(9):657-65.

20. Boyce WJ, Vessey MP. Rising incidence of fracture of the proximal femur. Lancet. 1985;1(8421):150-1

21. Mazzuoli GF, Gennari C, Passeri M, Celi FS, Acca M, Camporeale A, et al. Incidence of hip fracture: an Italian survey. Osteoporos Int.1993;3(Suppl 1):8-9.

22. Meier DE, Luckey MM, Wallenstein S, Clemens TL, Orwoll ES, Waslien CI. Calcium, vitamin $\mathrm{D}$, and parathyroid hormone status in young white and black women: association with racial differences in bone mass. J Clin Endocrinol Metab. 1991;72(3):703-10.

23. Kleerekoper M, Nelson DA, Peterson EL, Flynn MJ, Pawluszka AS, Jacobsen $G$, et al. Reference data for bone mass, calciotropic hormones, and biochemical markers of bone remodeling in older (55-75) postmenopausal white and black women. J Bone Miner Res. 1994;9(8):1267-76.

24. Brandão CMA, Vieira JG. Fatores envolvidos no pico de massa óssea. Arq Bras Endocrinol Metab. 1999;43(6);401-8.

25. Parker MJ, Martin S. Falls, hip fractures and the weather. Eur J Epidemiol. 1994;10(4):441-2.

26. Pedrazzoni M, Alfano FS, Malvi C, Ostanello F, Passeri M. Seasonal variation in the incidence of hip fractures in Emilia-Romagna and Parma. Bone. 1993;14(Suppl 1):S57-63.

27. Aharonoff GB, Dennis MG, Elshinawy A, Zuckerman JD, Koval KJ. Circumstances of falls causing hip fractures in the elderly. Clin Orthop Relat Res. 1998;(348):10-4.

28. Parker MJ, Twemlow TR, Pryor GA. Environmental hazards and hip fractures. Age Ageing. 1996;25(4):322-5.

29. Crawford JR, Parker MJ. Seasonal variation of proximal femoral fractures in the United Kingdom. Injury. 2003;34(3):223-5.

30. Douglas S, Bunyan A, Chiu KH, Twaddle B, Maffulli N. Seasonal variation of hip fracture at three latitudes. Injury. 2000;31(1):11-9.

31. Jacobsen SJ, Sargent DJ, Atkinson EJ, O'Fallon WM, Melton LJ 3rd. Population-based study of the contribution of weather to hip fracture seasonality. Am J Epidemiol. 1995;141(1):79-83.

32. Lau EM, Gillespie BG, Valenti L, O'Connell D. The seasonality of hip fracture and its relationship with weather conditions in New South Wales. Aust J Public Health. 1995;19(1):76-80.

33. Wickham CA, Walsh K, Cooper C, Barker DJ, Margetts BM, Morris J, et al. Dietary calcium, physical activity, and risk of hip fracture: a prospective study. BMJ. 1989;299(6704):889-92.

34. Dunitz, M. Osteoporosis: diagnosis and management. London: Martin Dunitz; 1998. p. 1-16.

35. Cooper C, Barker DJ, Wickham C. Physical activity, muscle strength, and calcium intake in fracture of the proximal femur in Britain. BMJ. 19883;297(6661):1443-6.

36. Cummings SR, Nevitt MC, Browner WS, Stone K, Fox KM, Ensrud KE,et al. Risk factors for hip fracture in white women. Study of Osteoporotic Fractures Research Group. N Engl J Med. 1995;332(12):767-73. 